\title{
BIAŁOWIEŻA FOREST (NE-POLAND) AND VALDAY NP (NW-RUSSIA) - BIOGEOGRAPHICAL CHARACTERISTICS OF EUTROPHIC DECIDUOUS FORESTS
}

\author{
Jan Marek Matuszkiewicz ${ }^{1}$, Elena Bielonowska², Anna Kowalska ${ }^{1}$, \\ Nadjeżda CariewsKa ${ }^{2}$, JarosŁaW Baranowski ${ }^{1}$, Viera Vinogradowa ${ }^{2}$, \\ ArKadi TishKov², Elena LitVinOVA ${ }^{3}$ \\ ${ }^{1}$ Institute of Geography and Spatial Organization, Polish Academy of Sciences, Warsaw, Poland \\ ${ }^{2}$ Institute of Geography Russian Academy of Sciences, Moscow, Russia \\ ${ }^{3}$ Valdaisky National Park, Valday, Russia
}

Manuscript received: June 21, 2014

Revised version: August 3, 2014

\begin{abstract}
Matuszkiewicz J.,M., Bielonowska E., Kowalska A., Cariewska N., Baranowski J., Vinogradowa V., Tishkov A., Litvinova E., 2014. Białowieża Forest (NE-Poland) and Valday NP (NW-Russia) - biogeographical characteristics of eutrophic deciduous forests. Quaestiones Geographicae 33(3), Bogucki Wydawnictwo Naukowe, Poznań, pp. 111-122, 2 tables, 5 figs. DOI 10.2478/quageo-2014-0034, ISSN 0137-477X.

AвSTRACT: During geobotanical studies in the north-eastern border of hemi-boreal zone, in Valday (NW Russia), rare eutrophic deciduous forests dominated by oak Quercus robur were observed. A comparison of these forests with the model of European deciduous forest in Białowieża National Park (NE-Poland) indicates a great similarity. Therefore, eutrophic deciduous forests in Valday can be classified to the Querco-Fagetea class, the Fagetalia sylvaticae order and to the Capinion betuli alliance, despite the absence of hornbeam Carpinus betulus in the region. Rarity of eutrophic deciduous forests in Valday region results probably from strong anthropogenic pressure in the past.
\end{abstract}

KEY WORDS: hemiboreal and nemoral eutrophic deciduous forests; biogeographical characteristic

Address of the corresponding author: Jan Marek Matuszkiewicz, Institute of Geography and Spatial Organization, Polish Academy of Sciences, Twarda 51/55, 00-818 Warszawa, Poland; e-mail: jan.mat@twarda.pan.pl

\section{Introduction}

The role of eutrophic deciduous forests in a transition zone between boreal coniferous (Northern Europe) and deciduous forests (Western Europe) has not been explained sufficiently so far. Eutrophic deciduous forests belong to the Querco-Fagetea class and the Fagetalia sylvaticae order. On the one hand, they are thought to have minor significance in rich habitats of the hemiboreal zone compared to spruce forests (Ahti et al. 1968, Lavrenko 1980, Korotkov 1991), on the other they are important type of potential natural vegetation and their present rarity results from long, sustained human activity (Lavrenko 1980, Dyrenkov, Avdeev 1989).

The aim of this study was to quantify the phytosociological and biogeographical differences and similarities in plant species composition across two regional forms of eutrophic deciduous forests. The first one is found in the centre of European deciduous forests range (Białowieża Forest - BF) and constitutes a reference area, the second is found in its peripheral zone (Valday 
National Park - V). The differences were related to the climatic conditions of the studied regions.

\section{Study objects}

The study was conducted in two forest complexes in Poland and in Russia, situated at the distance of $\sim 830 \mathrm{~km}$ (Fig. 1). Białowieża Forest $\left(52^{\circ} 42^{\prime} \mathrm{N} ; 23^{\circ} 51^{\prime}\right.$ E) constituted a reference area for the forest complex in Valday National Park $\left(57^{\circ} 58^{\prime} \mathrm{N} ; 33^{\circ} 17^{\prime} \mathrm{E}\right)$. The studied forests were classified, according to Braun-Blanquet's method (Westhoff, van der Maarel 1978, MuellerDombois, Ellenberg 2003) as two regional forms of eutrophic deciduous forest belonging to the Querco-Fagetea class and the Fagetalia sylvaticae order. Generally, eutrophic deciduous forests encompass a very broad spatial range in Europe. It covers the area from Atlantic Ocean in the west to Ural Mountains in the east and from the southern border of boreal coniferous forests in the north to Mediterranean and steppe zones in the south. Eutrophic deciduous forests play an important role

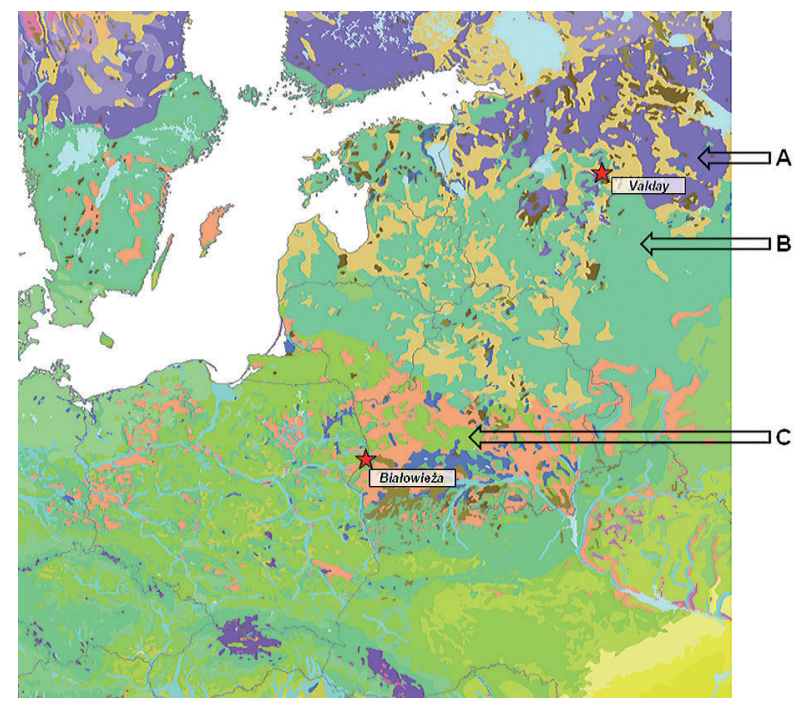

Fig. 1. Location of the studied forest complexes: Białowieża Forest and Valday National Park on the Map of the Natural Vegetation of Europe (2004)

A - Southern boreal coniferous and mixed broad-leaved-coniferous forests; Scandinavian-east European spruce forests partly with Tilia cordata and Corylus avellana, with herbs, dwarf shrubs and mosses. B - Hemiboreal spruce forests with broad-leaved trees; Baltic-northwest Sarmatian herb-rich mixed broad-leaved-spruce forests (Picea abies, Tilia cordata, Acer platanoides, Quercus robur) with Corylus avellana, Euonymus verrucosa, Galeobdolon luteum, Stellaria holostea.

C - Mesophytic deciduous broad-leaved and mixed coniferous-broad-leaved forests; Mixed oak-hornbeam forests (Carpinus betulus, Quercus robur, Q. petraea, Tilia cordata) in the vegetation of central Europe and of Poland as well. They have zonal character and constitute a climax type of natural community (potential natural vegetation). However, in Eastern Europe, especially in hemi-boreal zone they are not widespread, mainly due to human pressure.

Białowieża Forest is a complex of ancient forest (Peterken 1977, Rackham 1980). It has not been deforested since ages due to game objectives, especially in the area of Białowieski National Park. Białowieża Forest is regarded as nearly natural community with primeval forest characteristics. The lime-oak-hornbeam forest of Tilio-Carpinetum association belonging to the Carpinion betuli alliance (o. Fagetalia sylvaticae, c. Querco-Fagetea) is the most common type of natural community in Białowieża Forest. Almost all species characteristic of the alliance with hornbeam Carpinus betulus ahead can be found there. The lime-oakhornbeam forests in BF have been phytosociologically and ecologically examined in detail. It is probably the best known type of lowland forest in Europe and can serve as a benchmark for the similar forest communities in the continent. First research of the lime-oak-hornbeam forests was carried out in 1920s by Józef Paczoski (pioneer of Polish phytosociology), then in 1940s by Matuszkiewicz (1952) and later by others: Sokołowski (1993), Faliński (1995), Matuszkiewicz et al. (2007). They left a very rich collection of phytosociological relevés. The Tilio-Carpinetum association in $\mathrm{BF}$ shows a great habitat diversity and therefore can be divided into several subassociations. The most important are: Tilio-Carpinetum calamagrostietosum on poor sandy-clay soils, T.-C. typicum on rich, fresh clay soils, T.-C. stachyetosum on moist clay soils and T.-C. melittetosum with significant share of light-demanding species. First three mentioned subassociations have been quite stable for last 50 years (Matuszkiewicz $2007,2011)$ that indicates their natural character and a lack of human impacts. Instead, the subassociation with Melittis melissophyllum has been declined since 1960s and is very rare at present. The thinned stand with pine and light-demanding species from grasslands and oak forests in the herb layer clearly indicate anthropogenic or zoo-anthropogenic origin.

Contrary to BF, the forests ecosystems in Valday National Park (Russia) have been not care- 
fully examined. They are located on the northeast edge of hemi-boreal spruce forests with broad-leaved trees (Quercus robur L., Tilia cordata Mill., Ulmus glabra Huds., Acer platanoides L.) bordering on the east with southern boreal type of mesophytic and hygromesophytic coniferous and mixed broad-leaved-coniferous forests (Map of the natural vegetation of Europe, 2004). They are located far away from the east border of hornbeam range therefore can hardly be classified to the Carpinion betuli alliance. Moreover, they have been put under intense human pressure inter alia selective tree cutting (valuable species like oak and lime; Korotkov 1991, Nikonov 2003; Tishkov 2014). The forest stands situated on clay soils of end moraines are dominated by oak with other species in addition. Similarly to BF, oak forests in Valday show habitat diversity and can be divided into three types: poor with Calamagrostis arundinacea, Vaccinium myrtillus and other acidophilus species, typical on rich habitats and moist type. Their species richness is also comparable: about 40 herbs and ground moss species. The oak forests in Valday can be classified as a phytocenon belonging to the Querco-Fagetea class and the Fagetalia sylvaticae order but their affiliation to an alliance or an association is ambiguous. It can be ascertain that they represent East European association of Trollio-Quercetum described by Korotkov (1991) belonging to Querco-Fagetea. The studied forest complex is moderately deformed with thinned stand and open habitat species. It is uncommon in Valday region dominated by spruce communities.

\section{Materials and methods}

The analysis of plant species composition was based on phytosociological relevés collected in accordance with the Braun-Blanquet methodology (1964). The data set consisted of 503 relevés from BF, situated in the national park (Matuszkiewicz 1952, Sokołowski 1993, Faliński 1995, Matuszkiewicz 2007). The 6 relevés from Valday National Park (Russia) were collected in July 2013, in plots situated within a radius of $1-2 \mathrm{~km}$, in the west part of the park. Their characteristics, therefore, can be a bit accidental.
To explore differences in plant species composition across the studied forest complexes, species frequency was calculated for the indentified forest associations. In $\mathrm{BF}$, forests were divided into 4 subassociations or were calculated together like in Valday NP. To compensate the great discrepancy in the number of relevés between the forest complexes, all species absent in Valday $\mathrm{NP}$ and present in less than $1 / 6$ of relevés in BF were skipped.

The species affiliation to syntaxonomic units (acc. to Matuszkiewicz 2001, Zając, Zając 2009) and geographical elements (Zając, Zając 2009) was determined. The species presence in the regions was ascertained with the floristic sources (BF - Zając, Zając 2001; V - Morozova et al. 2010). The analysis concerned only vascular plant species; moss species were skipped because they are not classified regarding geographical elements.

The calculations of the species frequency in groups characteristic of various syntaxonomic units provided results of so-called systematic group values for:

- typical lime-oak-hornbeam forests of Carpinion betuli alliance,

- other eutrophic deciduous forests of Querco-Fagetea class,

- pine forests of Vaccinio-Piceetea class, and

- other syntaxonomic units.

Biogeographical analysis was carried out on plant species lists in two forest complexes (BF - all subassociations together) without taking into account species frequency. The share of geographical elements and sub-elements (Zając, Zając 2009) was calculated in the forest plant composition.

The climatic conditions of the studied regions were investigated comparing thermal (mean month temperature) and pluvial (total month precipitation) data, according to Chomicz (1977) and Spravochnik po klimatu SSSR (1965; 1968). To quantify climate influence on deciduous forest vegetation two pluvio-thermal indicators were calculated, proposed by Ellenberg (1978) (1) and Matuszkiewicz (2001) - (2):

$$
\text { PTI-E }=t_{\mathrm{vII}} / \mathrm{P}_{\mathrm{ann}} \times 1000
$$

where $t_{V I I}$ is mean temperature in July, $P_{a n n}$ mean annual precipitation, 


$$
\begin{gathered}
\text { PTI-M }=\left(P_{\mathrm{V}} / 3-t_{\mathrm{v}}\right)+\left(P_{\mathrm{VI}} / 3-\mathrm{t}_{\mathrm{VV}}\right)\left(\mathrm{P}_{\mathrm{VII}} / 3-\mathrm{t}_{\mathrm{VII}}\right) \\
\left(\mathrm{P}_{\mathrm{VIII}} / 3-\mathrm{t}_{\mathrm{VIII}}\right)\left(\mathrm{P}_{\mathrm{IX}} / 3-\mathrm{t}_{\mathrm{IX}}\right)
\end{gathered}
$$

where $P_{V . I X}$ is total mean precipitation in May to September, $t_{V \ldots I X}$ mean temperature in May to September.

Originally, they were applied to indicate the climate conditions favourable for beech in Central Europe. This is fulfilled when PTI-E is lower than 30 and PTI-M is higher than 35.

\section{Results}

\section{Analysis of differences in characteristic species frequency}

The frequency of vascular plant species characteristic of the respective syntaxonomic units is presented in Table 1. The most important for the studied forest complexes are two classes aggregating eutrophic deciduous forests - Querco-Fagetea class and coniferous forests - Vaccinio-Piceetea class. A significant part of the plant composition in the studied forests consists of species characteristic of the Querco-Fagetea class. Their total frequency in BF in subassociations of Tilio-Carpinetum calamagrostietosum and T.-C. melittetosum amounts about $45 \%$ and in T.-C. typicum and T.C. stachyetosum $67-68 \%$. In Valday total frequency of these species is only slightly lower than in the poorer subassociations of $\mathrm{BF}$.

The share of species characteristic of the whole Querco-Fagetea class is similar in BF (in all subassociations) and Valday and amounts $15-20 \%$ of the species composition (Fig. 2). The species characteristic of the Fagetalia sylvaticae order are more diverse. In poorer subassociations of BF these species amount $12-16 \%$ and even $30 \%$ in rich subassociations. Comparing BF and Valday NP, this difference is smaller, a few percent in favour of BF.

The obtained results confirm that the forests complex in Valday NP can be classified to the Querco-Fagetea class and the Fagetalia sylvaticae order despite distant border of the beech Fagus sylvatica range which name is included in the class and order names.

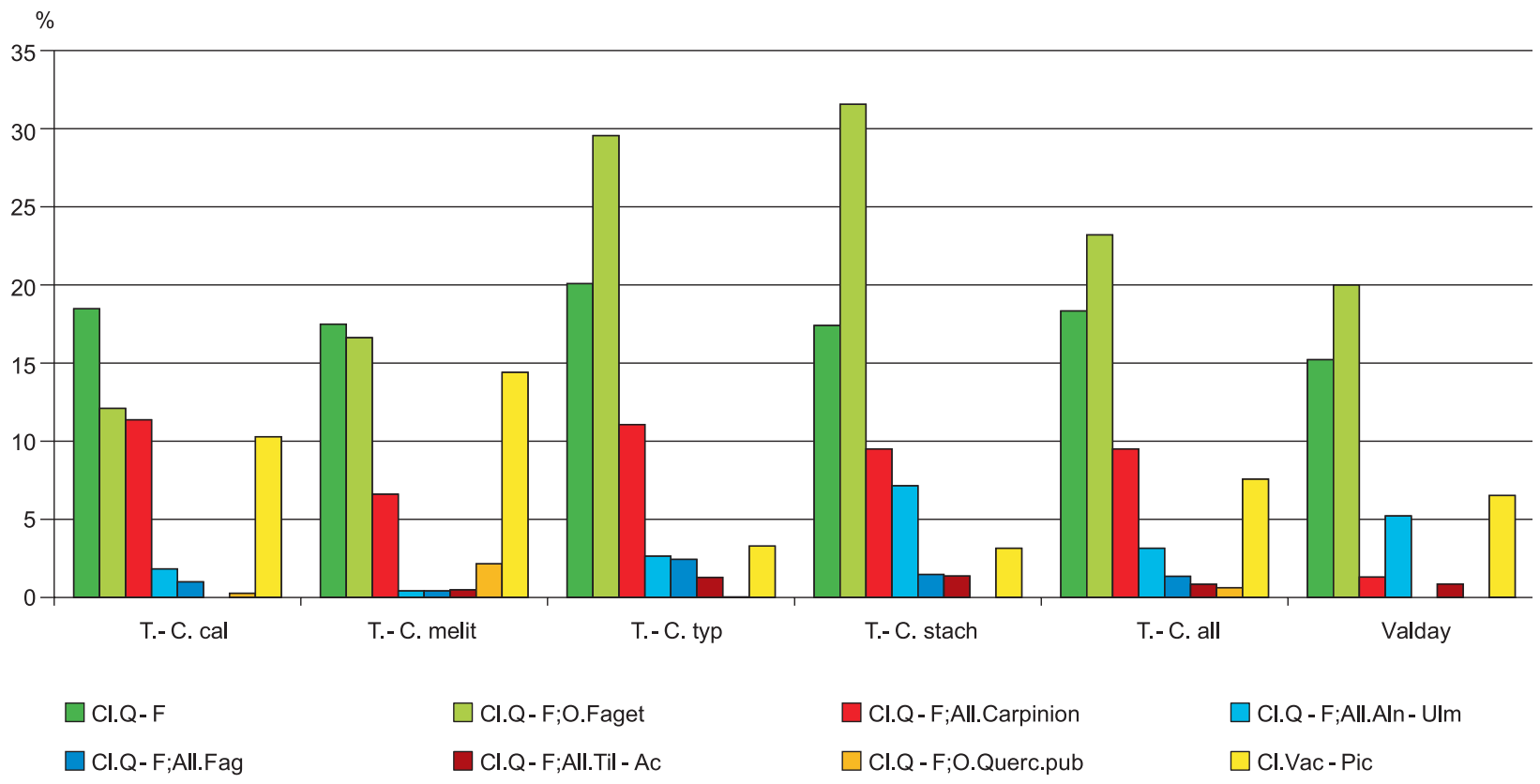

Fig. 2. Total frequency of vascular species characteristic of two phytosociological classes in the studied forest complexes Cl.Q-F - species characteristic of Querco-Fagetea class Cl.Q-F;O.Faget - species characteristic of Fagetalia sylvatici order Cl.Q-F;All.Carpinion - species characteristic of Carpinion betuli alliance Cl.Q-F;All.Aln-Ulm - species characteristic of Alno-Ulmion alliance Cl.Q-F;All.Fag - species characteristic of Fagion alliance

Cl.Q-F;All.Til-Ac - species characteristic of Tilio-Acerion alliance Cl.Q-F;O.Querc.pub - species characteristic of Quercetalia pubescenti order Cl.Vac-Pic - species characteristic of Vaccinio-Piceetea class 
Only one from four species characteristic of the Carpinion betuli alliance frequent in BF was noticed in Valday, namely: Stellaria holostea. The Tilia cordata and Carex pilosa although present in the region, were not observed in the studied forests, probably because of anthropogenic pressure. The Carpinus betulus is not present in the regional flora of Valday NP. The absence of this species raises doubts if forests in Valday NP can be classified like in BF to the Carpinion betuli alliance. The Figure 2 shows that the share of species characteristic of this alliance is there definitely smaller than in Białowieża Forest.

Species characteristic of other syntaxonomic units, included in the Querco-Fagetea class are less important. However, there is a significant share of species characteristic of Alno-Ulmion alliance in Valday NP forests. They resemble moist subassociations in BF. There is also a slight share of species characteristic of Fagion alliance in BF that are not recorded in Valday.

Differences in the share of species characteristic of the Vaccinio-Piceetea class divide poor and rich subassociations in BF (bigger and smaller share respectively). There is not such a difference between BF and Valday although the forest complex in Valday NP is located near the boreal coniferous forest zone.

Based on the obtained results the forest complex in Valday cannot be unambiguously classified to the Carpinion betuli alliance but it cannot be precluded. Furthermore, it seems there is not an alternative possibility - another alliance. In that case, forests in Valday should be classified as a borderland form of eutrophic deciduous forests of the Carpinion betuli alliance. The absence of Carpinus betulus is not so important alike in case of Fagus sylvatica absence for the classification of the Querco-Fagetea class and the Fagetalia sylvaticae order.

The share of species characteristic of open habitats amounts $6-7 \%$ in $\mathrm{BF}$ and three times as much (over 22\%) in Valday NP (Fig. 3). In the BF, the species characteristic of Epilobietea angustifoliae (clearings communities), Artemisietea (ruderal and forest fringe communities), and Trifolio-Geranietea (thermophilous tall herbs communities) are the most frequent. All these species groups are integrally related to forest habitats. Their presence is associated with forest ageing and occur-

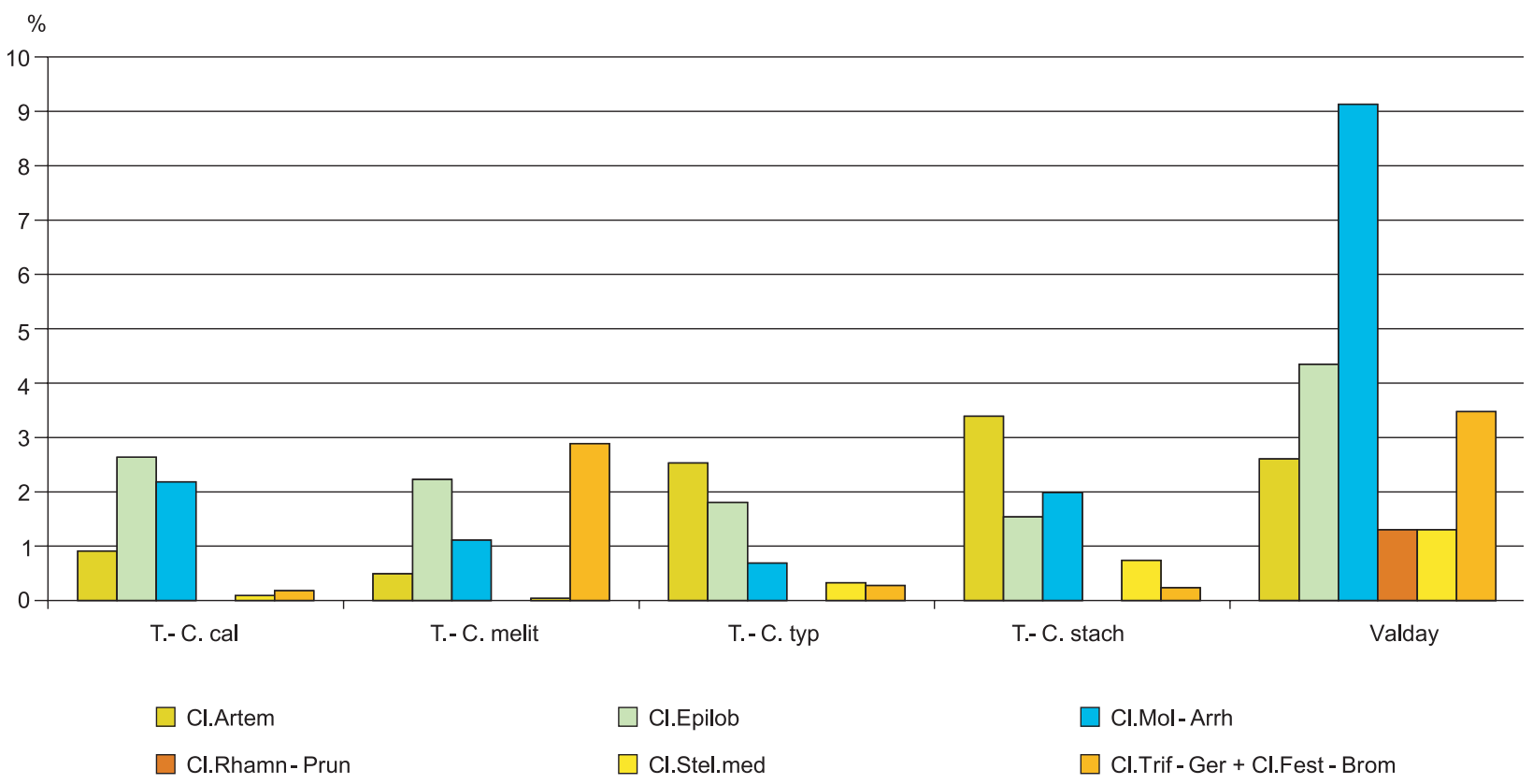

Fig. 3. Total frequency of vascular species characteristic of open habitats in the studied forest complexes Cl.Artem - species characteristic of Artemisietea class (ruderal and forest fringe communities) Cl.Epilob - species characteristic of Epilobietea angustifolii class (clearings communities) Cl.Mol-Arrh - species characteristic of Molinio-Arrhenatheretea class (grassland communities) Cl.Rhamn-Prun - species characteristic of Rhamno-Prunetea class (shrub communities) Cl.Stel.med - species characteristic of Stellarietea mediae class (segetal and ruderal communities) communities) 


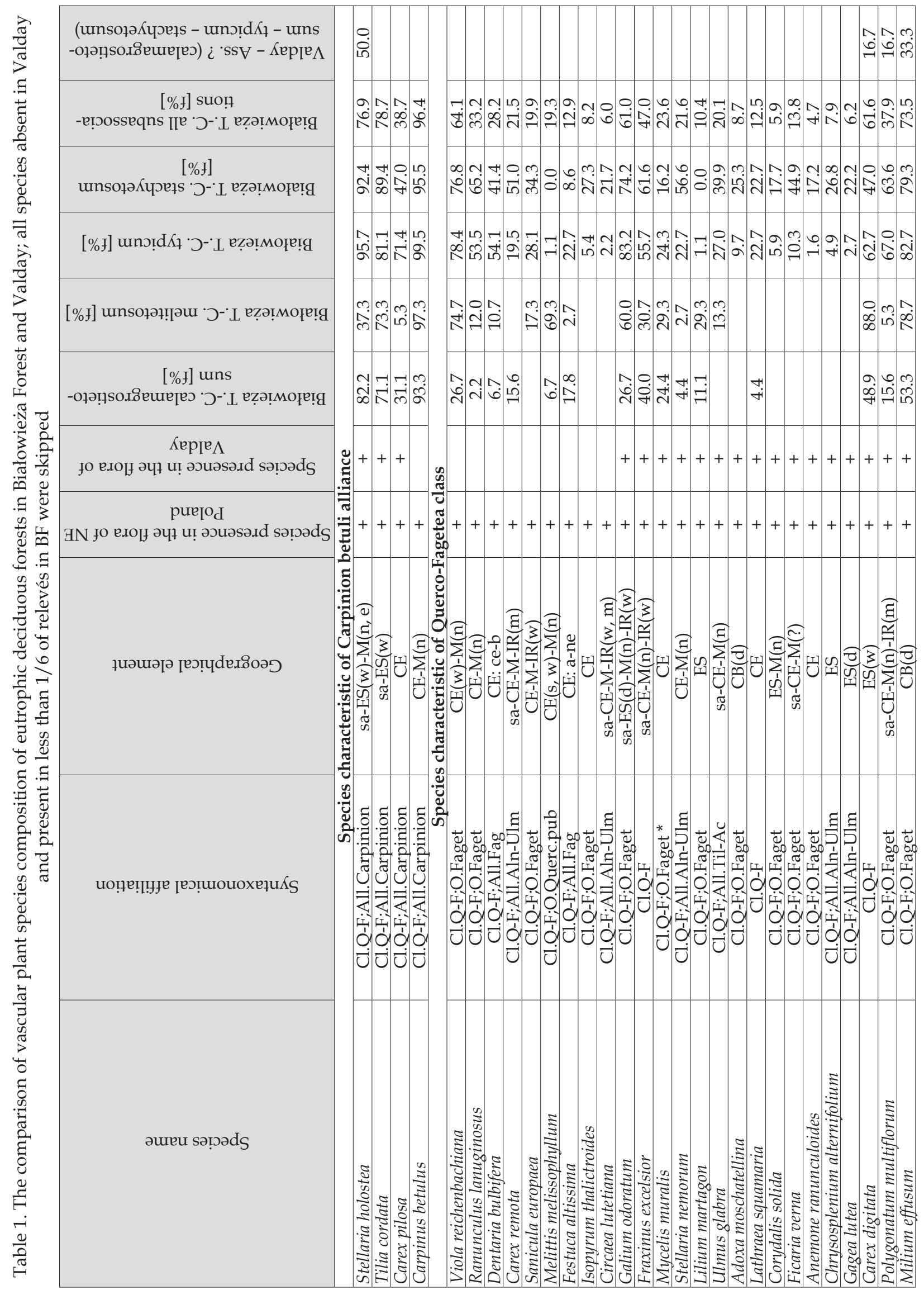




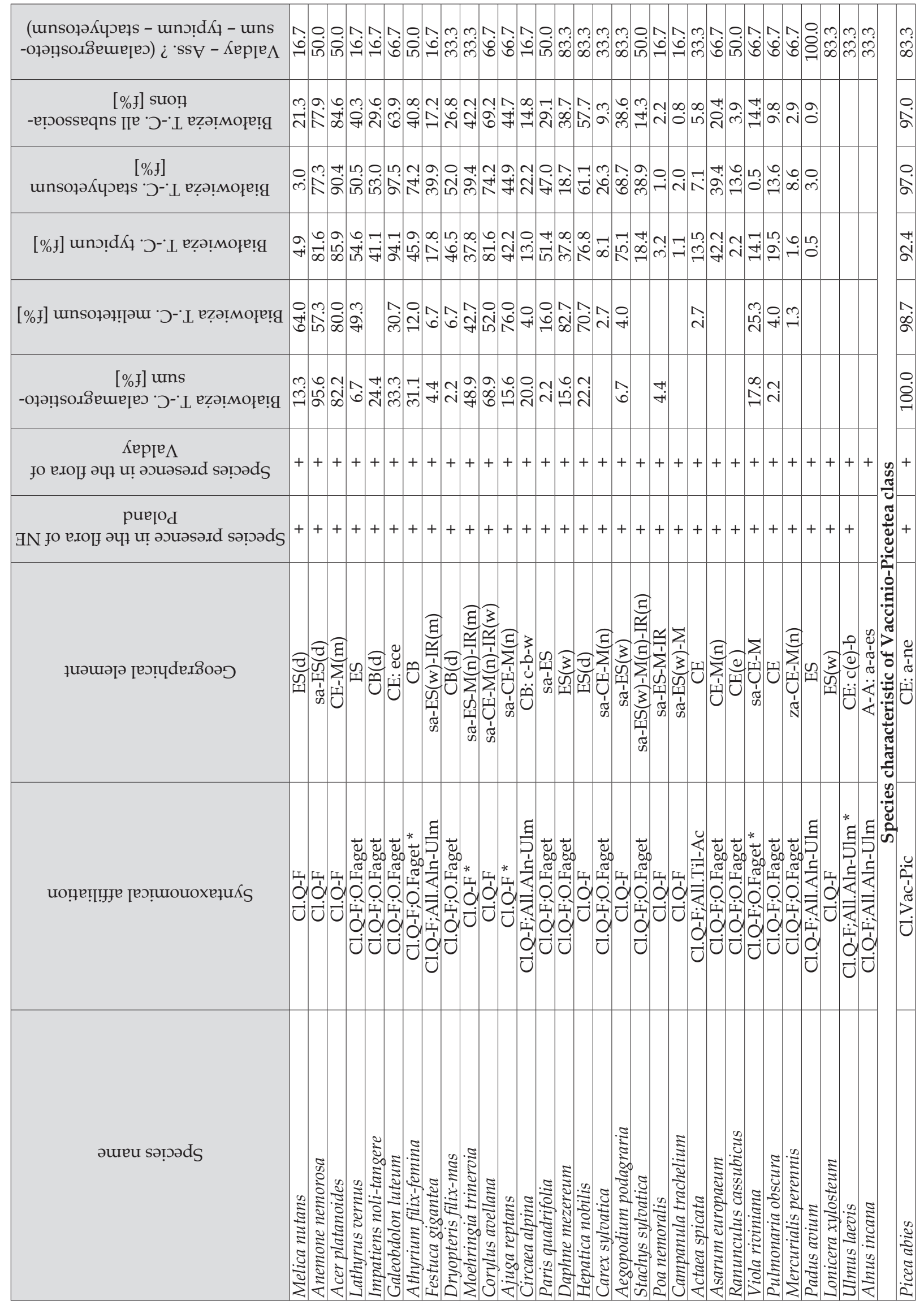




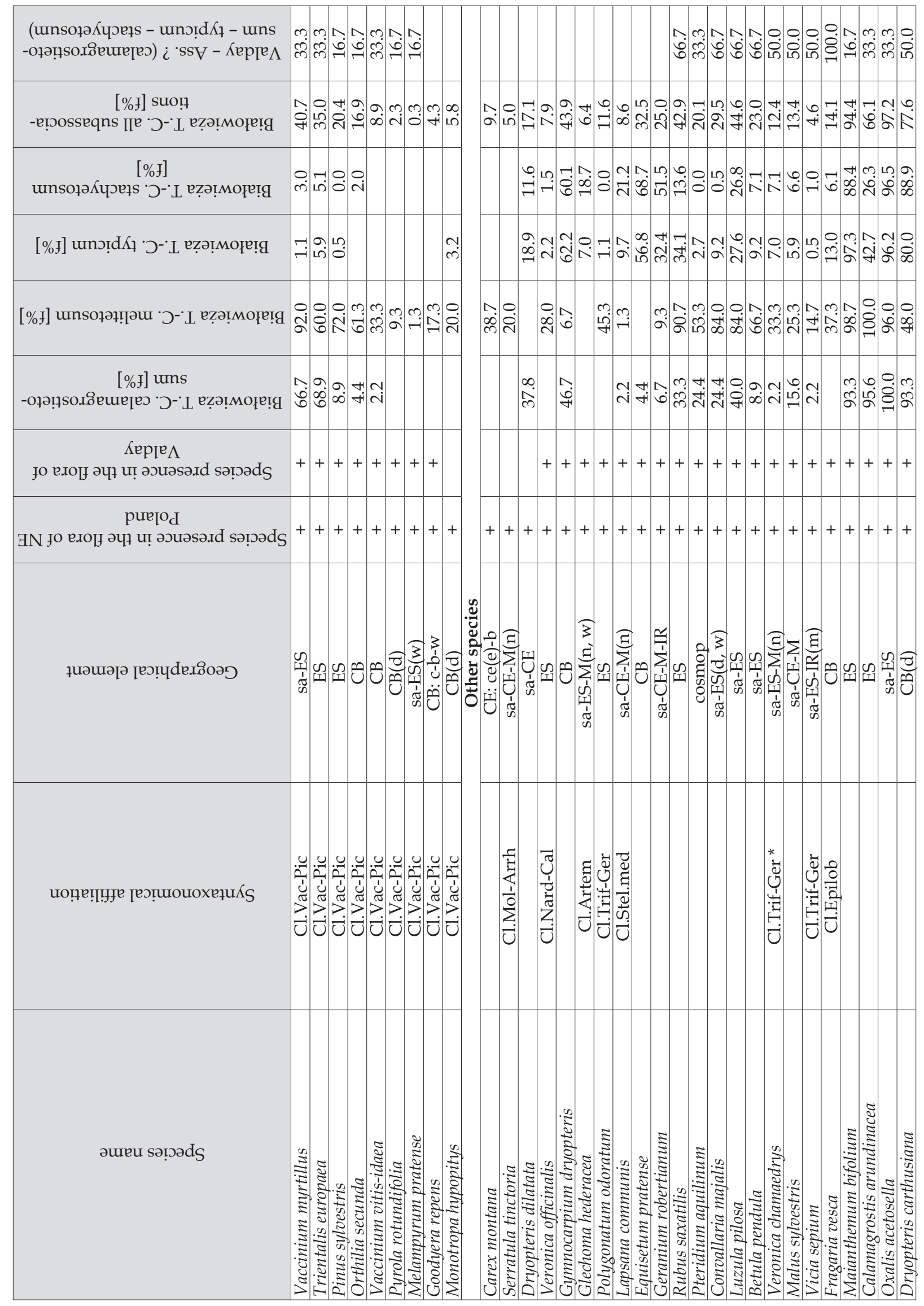




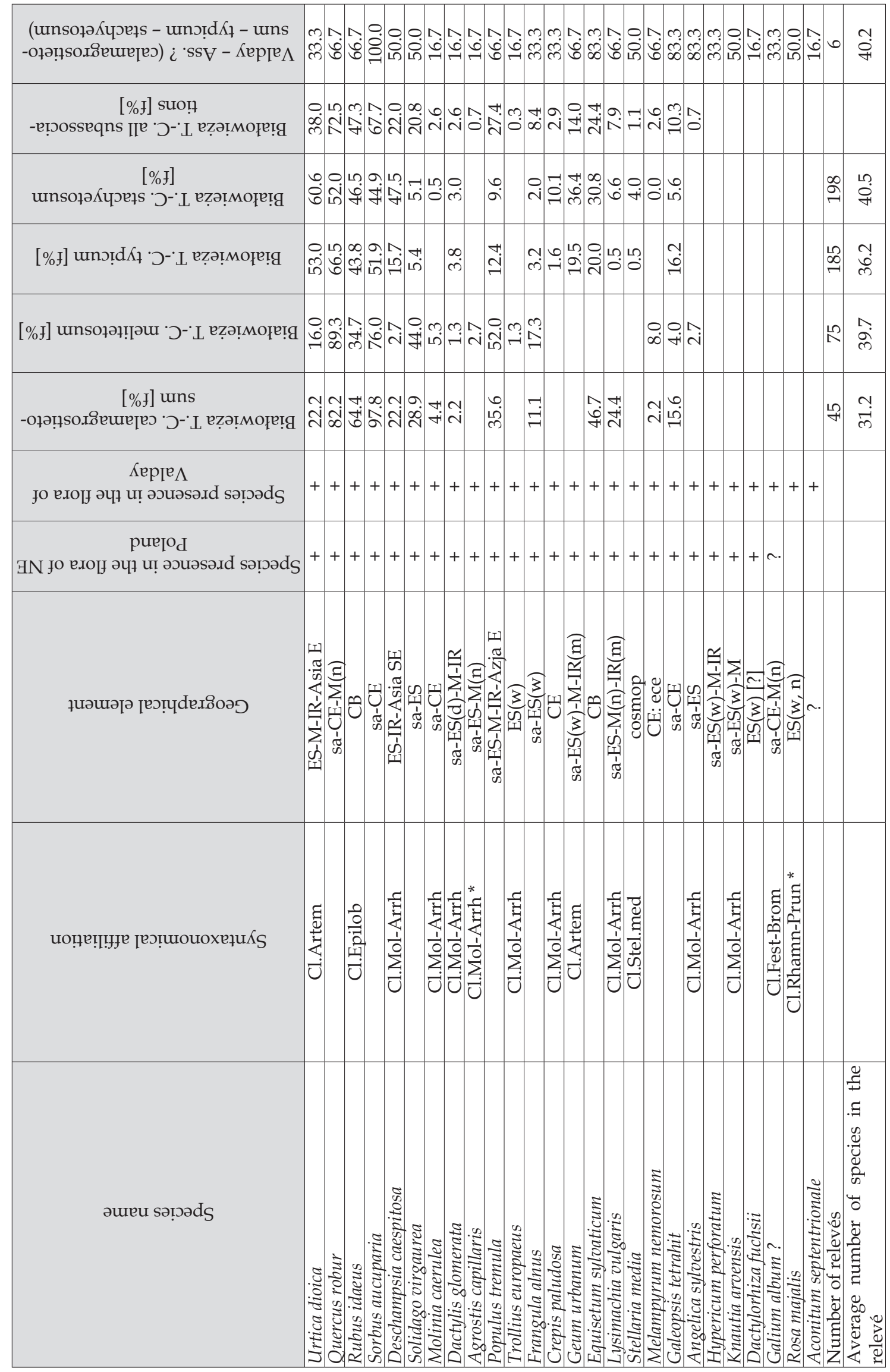


rence of gaps caused by trees throw. Their slight share in forests corresponds with the model of natural deciduous forest. In Valday NP, besides above mentioned groups, species of Molinio-Arrhenatheretea class (grassland communities) are quite frequent. This indicates past anthropogenic pressure - livestock grazing resulting in grassland species dispersal. These effects are in line with the observations of many forests in Poland (Matuszkiewicz et al. 2007).

\section{Analysis of biogeographical differences in plant species composition}

Biogeographical characteristics of plant species composition in the studied forest complexes is presented in Figure 4. Geographical sub-elements were assigned to all vascular plant species. The majority of plant species composition in both complexes belongs to Holarctic element (58\% in BF and 63\% in Valday). A significant part of species constitutes connective Holarctic-Mediterranean or Holarctic Irano-Turanian elements. European-temperate sub-element and connective elements: European-temperate-Mediterranean and European-temperate-Mediterranean-Irano-Turanian are more frequent in $\mathrm{BF}$ (together $41 \%$ in $\mathrm{BF}$ and $27 \%$ in Valday), while Euro-Siberian sub-element and connective Euro-Siberian-Mediterranean-Irano-Turanian element are more frequent in Valday (54\%). Circum-Boreal sub-element has similar share in both regions $(15 \%)$ while cosmopolitan element is rare in both regions. The Arctic-Alpine sub-element is only present in Valday NP.

Summing up, both forest complexes are quite similar, although, due to forests location there are more European-temperate sub-elements in BF and Euro-Siberian sub-elements in Valday NP. Through their biogeographical similarity, the studied forests can be regarded as two vicarious units within Carpinion betuli alliance.

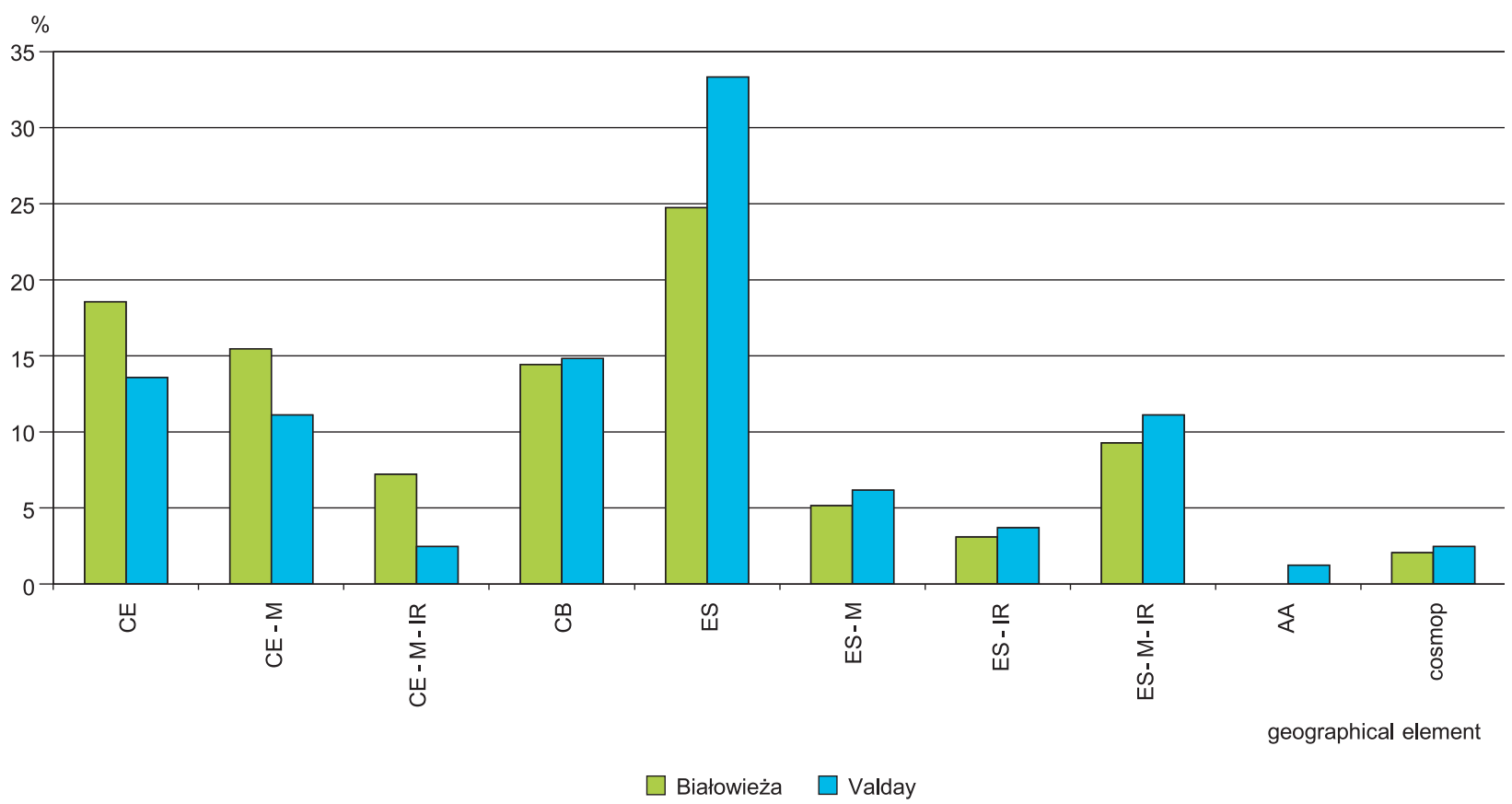

Fig. 4. Biogeographical characteristics of flora in studied forest complexes. Geographical elements and sub-elements acc. to Zając, Zając (2009)

CE - Holarctic element; European-temperate sub-element

CE-M - Conective element: European-temperate - Mediterranean

CE-M-IR - Conective element: European-temperate - Mediterranean - Irano-Turanian

CB - Holarctic element; Circum-Boreal sub-element

ES - Holarctic element; Euro-Siberian sub-element

ES-M - Conective element: Euro-Siberian - Mediterranean

ES-IR - Conective element: Euro-Siberian - Irano-Turanian

ES-M-IR - Conective element: Euro-Siberian - Mediterranean - Irano-Turanian AA - Holarctic element; Arctic-Alpine sub-element cosmop - Cosmopolitan element 


\section{Analysis of differences in climatic conditions}

The differences between the studied regions are highly visible in the climatic conditions (Table 2). Mean annual temperature in Valday NP is $3^{\circ} \mathrm{C}$ lower than in Białowieża Forest what is mainly caused by cooler winter months. The differences in mean month temperatures in winter exceed $5^{\circ} \mathrm{C}$. In contrast, the mean temperatures of summer months are quite similar, the mean temperature in July is only $1^{\circ} \mathrm{C}$ lower in Valday NP than in Białowieża Forest. The annual temperature amplitude is significantly higher in Valday NP than in $\mathrm{BF}$ what indicates the climate continentality.
Annual precipitation is generally higher in Valday NP. Average month precipitation is about $30 \%$ higher in this region but it changes during a year. However, in May, mean month precipitation is higher in Białowieża.

The pluvio-thermal indicators show that climatic conditions are even more favourable for beech habitats in Valday NP than in Białowieża Forest. The question is how this species would adapt to thermal conditions of winter season. The actual range of beech is distant form Białowieża Forest and Valday NP but it seems that their climatic conditions are adequate for plant species adapted to temperate cool and humid climate.

The climate conditions of Valday are more severe and continental in temperature but also

Table 2. The climatic conditions of the studied regions

\begin{tabular}{|c|c|c|c|c|}
\hline \multicolumn{2}{|c|}{ Name of the station } & Białowieża & Valday & Difference (V-B) \\
\hline \multicolumn{2}{|c|}{ Latitude } & $52^{\circ} 42^{\prime}$ & $57^{\circ} 58^{\prime}$ & $5^{\circ} 16^{\prime}$ \\
\hline \multicolumn{2}{|l|}{ Longitude } & $23^{\circ} 51^{\prime}$ & $33^{\circ} 17^{\prime}$ & $9^{\circ} 26^{\prime}$ \\
\hline \multicolumn{2}{|l|}{ Altitude $\mathrm{m}$ a.s.l. } & 164 & 201 & 37 \\
\hline \multirow{14}{*}{ Mean month precipitation } & annual & 600 & 828 & 228 \\
\hline & I & 34 & 56 & 22 \\
\hline & II & 36 & 49 & 13 \\
\hline & III & 31 & 52 & 21 \\
\hline & IV & 45 & 55 & 10 \\
\hline & $\mathrm{V}$ & 62 & 58 & -4 \\
\hline & VI & 70 & 85 & 15 \\
\hline & VII & 70 & 92 & 22 \\
\hline & VIII & 68 & 89 & 21 \\
\hline & IX & 52 & 85 & 33 \\
\hline & $\mathrm{X}$ & 42 & 72 & 30 \\
\hline & $\mathrm{XI}$ & 50 & 71 & 21 \\
\hline & XII & 40 & 64 & 24 \\
\hline & average & 50 & 69 & 19 \\
\hline \multirow{14}{*}{ Mean month temperature } & annual & 6.4 & 3.2 & -3.2 \\
\hline & I & -4.3 & -9.6 & -5.3 \\
\hline & II & -5.0 & -9.4 & -4.4 \\
\hline & III & -1.4 & -5.0 & -3.6 \\
\hline & IV & 6.3 & 2.8 & -3.5 \\
\hline & $\mathrm{V}$ & 11.9 & 9.9 & -2.0 \\
\hline & VI & 16.5 & 14.2 & -2.3 \\
\hline & VII & 17.7 & 16.6 & -1.1 \\
\hline & VIII & 16.5 & 14.8 & -1.7 \\
\hline & IX & 12.0 & 9.6 & -2.4 \\
\hline & $x$ & 7.1 & 3.4 & -3.7 \\
\hline & XI & 1.9 & -2.2 & -4.1 \\
\hline & XII & -2.0 & -7.2 & -5.2 \\
\hline & amplitude & 22.7 & 26.2 & 3.5 \\
\hline \multirow{2}{*}{$\begin{array}{l}\text { Pluvio-thermal } \\
\text { indicators }\end{array}$} & PTI-E & 29.5 & 20.0 & -9.5 \\
\hline & PTI-M & 32.7 & 71.2 & 38.5 \\
\hline
\end{tabular}


more humid than those in Białowieża Forest. However, the climatic differences during vegetation period, important for deciduous trees and many herbs, are significantly smaller. Therefore, similar vegetation communities can appear in both regions.

\section{Conclusions}

Eutrophic deciduous forests with plant species composition close to East-European forests of nemoral zone are also observed in hemi-boreal zone, even near its border with boreal coniferous forests. According to their geobotanical characteristics they can be classified to the Querco-Fagetea class and the Fagetalia sylvaticae order or even with some restrictions to the Capinion betuli alliance. This is possible due to similar (to Central European) climatic conditions in summer, despite considerable differences in winter season.

Rarity of eutrophic deciduous forests in Valday NP results probably from their stands degradation and deforestation, especially during strong agricultural pressure in the past. If this hypothesis proves to be true, the studied forest type can be important type of potential natural vegetation in the region.

\section{References}

Ahti T., Hamet-Ahti L., Jalas J., 1968. Vegetations zones and their sections in northwestern Europe. Annales Botanici Fennici 5(3): 169-211.

Braun-Blanquet J., 1964. Pflanzensoziologie, Grundzüge der Vegetationskunde 3. Aufl., Springer, Wien-New York.

Dyrenkov S.A., Avdeev A.N., 1989. Proshloe i nastoyachshee shyrokolystvennykh lesov Novgorodskoi oblasti. Bull. Moskovskogo obchshestva ispytatelei prirody. Otd. Biologia. 94(4): 89-101.

Ellenberg H., 1978. Vegetation Mitteleuropas mit den Alpen in ökologicher Sicht. E. Ulmer, Stuttgart.

Faliński J.B., 1995. Study area in the Białowieża Forest. In: Faliński J.B., Mułenko W. (eds) Cryptogramous plants in the forest communities of Białowieza National Park. Phytocoenosis V.7 (NS) Archivum Geobotanicum 4: 25-34.

Korotkov K.O., 1991. Lesa Valdaya [The forests of Valday]. Moscow: Nauka publ.
Lavrenko E.M. (Ed.), 1980. Rastitelnost' Evropeiskoi chasti SSSR (Vegetation of the European Part of the U.S.S.R.) Nauka, Leningrad.

Map of the Natural Vegetation of Europe. 2004. Federal Agency for Nature Conservation, Bonn.

Matuszkiewicz J.M., 2007. Zmiany w grądach, borach mieszanych i łęgach jesionowo-olszowych Puszczy Białowieskiej. In: Matuszkiewicz J.M. (Ed.). Geobotaniczne rozpoznanie tendencji rozwojowych zbiorowisk leśnych w wybranych regionach Polski. IGiPZ PAN Monografie 8: 197-290.

Matuszkiewicz J.M., 2011. Changes in the forest associations of Poland's Białowieża Primeval Forest in the second half of the 20th century. Czasopismo Geograficzne 82(1-2): 67-103.

Matuszkiewicz W., 1952. Zespoły leśne Białowieskiego Parku Narodowego. Annales UMCS Suppl VI: 1-218.

Matuszkiewicz W., 2001. Przewodnik do oznaczania zbiorowisk roślinnych Polski. Wyd. Nauk. PWN, Warszawa.

Morozova O.V., Carevskaya N.G., Belonovskaya E.A., 2010. Sosudistye rasteniya Nacional'nogo parka "Valdaiskii" (annotirovannyi spisok vidov). Moskva. Izdatel'stvo Komissii RAN po sohraneniyu biologicheskogo raznoobraziya i IPEE RAN. [Flora i fauna nacional'nyh parkov. Vyp. 7].

Mueller-Dombois D., Ellenberg H., 2003. Aims and Methods of Vegetation Ecology. The Blackburn Press.

Nokonov M.V., 2003. Ustoichivost' lesov $k$ prirodnym i antropogennym faktoram (na primere Novgorodskoi oblasti) [Sustainability of forests to nature and anthropogenic factors (on sample of Novgorod district)]. Velikiy Novgorod: Novgorod Uni. Publ.

Peterken, G.F., 1977. Habitat conservation priorities in British and European woodlands. Biological Conservation 11: 223-236.

Rackham, O., 1980. Ancient woodland its history, vegetation and uses in England. Arnold, London.

Sokołowski A.W., 1993. Fitosocjologiczna charakterystyka zbiorowisk leśnych Białowieskiego Parku Narodowego. Parki Narodowe i Rezerwaty Przyrody 12.3: 5-190.

Spravochnik po klimatu SSSR. Vypusk 3. Chast' 2. Izdatel'stvo Gidromet: Leningrad. 1965.

Spravochnik po klimatu SSSR. Vypusk 3. Chast' 4. Izdatel'stvo Gidromet: Leningrad. 1968.

Tishkov A.A., 2014. Landshaftnaya osnova proiskhozhdeniya nazvaniya Valday [Landscape basis of the origin of the name of the Valday]. Izvestiya Rossiskoi akademii nauk. Seriya geographicheskaya 1: 109-119.

Westhoff V., van der Maarel E., 1978. The Braun-Blanquet approach. In: Whittaker R.H. (ed.) Classification of plant communities. Junk, The Hague: 289-399.

Zając A., Zając M. (Ed.), 2001. Atlas rozmieszczenia roślin naczyniowych w Polsce. Pracownia chorologii Komputerowej Instytutu Botaniki UJ, Kraków.

Zając M., Zając A., 2009. The geographical elements of native flora of Poland. Institute of Botany Jagiellonian University, Kraków. 